\title{
MENINGKATKAN NILAI RASA DAN ESTETIKA BAHAN MASAKAN LOKAL SEBAGAI DAYA TARIK BAGI WISATAWAN PULAU TUNDA
}

\author{
Nila Prasetyo Artiwi \\ Teknik Sipil, Universitas Banten Jaya, J1 Syech Nawawi Albantani Serang, Banten, Indonesia \\ Email: prasetyonila2@gmail.com
}

\begin{abstract}
Tunda Island is a group of 17 islands in Serang Regency, Banten Province. Administratively, Tunda Island is located in Tirtayasa District, Serang Regency, Banten Province. Seen geographically, Pulau Tunda is located at coordinates $5^{\circ} 48^{\prime} 43^{\prime}$ 'latitude and $106^{\circ} 16^{\prime} 47^{\prime \prime}$. Tunda Island has become a very attractive tourism object because it has beautiful beaches and sea that can be explored as an attraction for tourists. The Banten Jaya University Research and Community Service Institute (LP3M) has won the trust of the Serang Regency Youth Sport and Tourism Service (Disporapar) as a companion to the Tunda Island Tourism Village to improve the quality of human resources in the tourism sector (Kabar Banten, 21/09/2020). The cooking demonstration activity is assisted by an experienced chef in order to increase human resource resources in the tourism sector and in order to increase the taste and aesthetic value of the local Tunda Island cuisine ingredients as an attraction in the form of offerings to Tunda Island tourists. As a result, the people of Tunda Island get knowledge and new menu alternatives from local food ingredients.
\end{abstract}

Keywords: Aesthetics; LP3M Unbaja; Local Food Ingridients; Tourist; Tunda Island.

\begin{abstract}
ABSTRAK
Pulau Tunda merupakan salah satu gugusan pulau dari 17 pulau yang berada di Kabupaten Serang Provinsi Banten. Secara administrative, Pulau Tunda terletak di Kecamatan Tirtayasa, Kabupaten Serang, Provinsi Banten. Dilihat secara geografis Pulau tunda terletak di koordinat $5^{\circ} 48^{\prime} 43^{\prime \prime}$ LS dan $106^{\circ} 16^{\prime}$ 47". Pulau Tunda sudah dijadikan objek pariwisata yang sangat menarik karena memiliki keindahan pantai dan laut yang bisa dieksplore sebagai daya tarik bagi wisatawan. Lembaga Penelitian dan Pengabdian Mayarakat (LP3M) Universitas Banten Jaya mendapatkan kepercayaan dari Dinas Pemuda Olahraga dan Pariwisata (Disporapar) Kabupaten Serang sebagai pendamping Desa Wisata Pulau Tunda untuk meningkatan kualitas sumber daya manusia dalam bidang pariwisata (Kabar Banten, 21/09/2020) melakukan kegiatan demo masak dibantu oleh seorang chef berpengalaman dalam rangka meningkatkan sumeber daya manusia di bidang pariwisata dan dalam rangka meningkatkan nilai rasa dan estetika bahan masakan local Pulau Tunda sebgai daya tarik berupa sajian kepada wisatawan Pulau Tunda. Hasilnya, masyarakat Pulau Tunda mendapatkan ilmu dan alternative menu baru dari bahan masakan local.
\end{abstract}

Kata Kunci: Bahan Masakan Lokal; Estetika; LP3M Unbaja; Pariwisata; Pulau Tunda.

\section{PENDAHULUAN}

Pariwisata merupakan berbagai macam kegiatan wisata yang didukung berbagai fasilitas serta layanan yang disediakan masyarakat, pengusaha, Pemerintah dan Pemerintah Daerah (Undang-undang No. 10 Tahun 2019 Tentang Kepariwisataan)'. Berdasarkan hal tersebut dapat dikatakan bahwa setiap wisatawan yang ingin melakukan perjalanan wisata kesuatu daerah 
tujuan wisata dengan tujuan rekreasi, pengembangan pribadi, mempelajari keuninkan daya tarik wisata sudah dipastikan akan membutuhkan faslitas, layanan serta informasi. Salah satu fasilitas yang dibutuhkan bagi wisatawan adalah tempat menginap didaerah tujuan wisata tersebut. Kebutuhan akan tempat menginap inipun menjadi salah satu hal menarik untuk dikaji hal ini disebabkan karena banyak wisatawan yang ingin mencoba menginap dan sekaligus berbaur dan bersosialisasi dengan warga sekitar. Atraksi wisata yang sesuai dengan keinginan wisatawan ini adalah dengan menjadikan rumah-rumah penduduk di sekitar daerah tujuan wisata dijadikan sebagai tempat menginap atau yang sering disebut dengan homestay. Jadi dengan demikian homestay adalah salah satu dari sekian banyak daya tarik wisata saat wisatawan mengambil keputusan untuk melakukan kunjungan di destinasi terutama desa wisata (Kemenpar, 2016). Secara prinsip, homestay adalah rumah tinggal penduduk di desa wisata yang sebagian kamarnya disewakan kepada wisatawan dengan keunggulan dapat melakukan interaksi aktif antara wisatawan dengan pemilik rumah (Kemenpar 2016). Kegiatan wisata yang berbasis sosiocultural-education akan membuka peluang dari masyarakat lokal kepada para wisatawan sebagai media pembelajaran social (social learning) dengan sikap interaksi langsung, bersosialisasi, berkomunikasi serta menjalin hubungan yang harmonis atas dasar saling menghormati, menghargai tradisi budaya lain (kearifan lokal). Hal ini bisa dilaksanakan dengan mengembangkan homestay yang awalnya hanya sebagai tempat menginap wisatawan namun dikembangkan menjadi salah satu atraksi wisata (Prasetyawati, 2018).

Sektor pariwisata di Indonesia saat ini diandalkan sebagai sektor alternatif untuk mendorong perekonomian Indonesia karena dua sektor yang selama ini diandalkan yaitu sektor industri dan sektor pertanian cenderung mengalami stagnasi. Dalam perkembangannya sektor pariwisata di Indonesia menghadapi berbagai masalah. Tujuan penelitian dalam tulisan ini adalah menganalisis sumbangan sektor pariwisata dalam perekonomian Indonesia dan masalahmasalah yang dihadapi sektor pariwisata di Indonesia serta bagaimana solusinya. Metode penelitian yang digunakan adalah deskriptif analitis dan kualitatif. Metode pengumpulan data adalah metode dokumentasi dari sumber sekunder. Hasil penelitian menunjukkan sumbangan sektor pariwisata terhadap perekonomian Indonesia sangat besar dalam bentuk sumbangannya terhadap PDB, penerimaan devisa dan penyerapan tenaga kerja. Sedangkan beberapa masalah yang dihadapi sektor pariwisata di Indonesia: peraturan yang tumpang tindih, kurangnya kualitas SDM, kurangnya publikasi, belum baiknya infrastruktur, masih kurangnya investasi, kurang diperhatikannya aspek lingkungan hidup, dan kurangnya perhatian pada objek wisata religi. Atas dasar masalah tersebut diusulkan kebijakan untuk mengatasi berbagai masalah tersebut yaitu menghapus tumpang tindih peraturan, peningkatan jumlah SDM yang bersertifikasi, publikasi yang lebih detil, dilanjutkannya pembangunan infrastruktur yang 
mendukung pariwisata, insentif bagi investor di sektor pariwisata, dan penegakkan hukum yang tegas atas pelanggaran yang menyebabkan rusaknya lingkungan hidup. Bagi penelitian lebih lanjut diusulkan penelitian dengan objek yang lebih detil (Nugroho, 2020).

Pengembangan industri pariwisata suatu daerah menjadi alasan utama sebagai salah satu upaya meningkatkan pendapatan asli daerah melalui pemanfaatan potensi-potensi daerah setempat. Pada dasarnya, pengembangan industri pariwisata suatu daerah berkaitan erat dengan pembangunan perekonomian daerah tersebut. Dampak positif yang secara langsung dapat dirasakan oleh masyarakat daerah setempat adalah adanya perluasan lapangan kerja secara regional. Ini merupakan akibat dari industri pariwisata yang berkembang dengan baik.

Sebagai dasar untuk mengkaji dan memahami berbagai istilah kepariwisataan, berpedoman pada Pengetahuan Dasar Ilmu Pariwisata 18 Bab I Pasal 1 Undang-Undang Republik Indonesia Nomor 10 Tahun 2009 tentang kepariwisataan yang menjelaskan sebagai berikut: 1. Wisata adalah kegiatan perjalanan yang dilakukan oleh sebagian atau sekelompok orang dengan mengunjungi tempat tertentu untuk tujuan rekreasi, pengembangan diri 2. Wisatawan adalah orang yang melakukan wisata 3. Pariwisata adalah berbagai macam kegiatan wisata dan didukung berbagai fasilitas serta layanan yang disediakan oleh masyarakat, pengusaha, pemerintah dan pemerintah daerah. 4. Kepariwisataan adalah keseluruhan kegiatan yang terkait dengan pariwisata dan bersifat multidimensi serta multidisiplin yang muncul sebagai wujud kebutuhan setiap orang dan negara serta interaksi antara wisatawan dan masyarakat setempat, sesama wisatawan, pemerintah, pemerintah daerah, dan pengusaha 5 . Daya tarik wisata adalah segala sesuatu yang memiliki keunikan, keindahan, dan nilai yang berupa keanekaragaman kekayaan alam, budaya dan hasil buatan manusia yang menjadi sasaran atau tujuan kunjungan wisatawan 6. Daerah Tujuan Pariwisata yang selanjutnya disebut destinasi pariwisata adalah kawasan geografis yang berada dalam suatu atau lebih wilayah administratif yang di dalamnya terdapat daya tarik wisata, fasilitas umum, fasilitas pariwisata, aksesibilitas serta masyarakat yang saling terkait dan melengkapi terwujudnya kepariwisataan 7 . Usaha pariwisata adalah usaha yang menyediakan barang dan/atau jasa pemenuhan kebutuhan wisatawan dan penyelenggaraan pariwisata 8. Pengusaha pariwisata adalah orang-orang atau sekelompok orang yang melakukan kegiatan usaha pariwisata 9. Industri pariwisata adalah kumpulan usaha pariwisata yang terkait dalam rangka menghasilkan barang dan/jasa bagi pemenuhan kebutuhan wisatawan penyelenggaraan pariwisata 10. Kawasan strategi pariwisata adalah kawasan yang memiliki fungsi utama pariwisata atau memiliki potensi untuk pengembangan pariwisata yang mempunyai pengaruh dalam suatu atau lebih aspek, seperti pertumbuhan ekonomi, sosial dan budaya, pemberdayaan sumber daya alam, daya dukung lingkungan hidup, serta pertahanan dan keamanan. 
Pengembangan pariwisata berkelanjutan kemudian muncul sebagai prinsip dasar pembangunan pariwisata yang holistik. Artinya dalam pelaksanaannya pengembangan pariwisata harus memperhatikan terhadap kelestarian lingkungan, pelibatan masyarakat setempat serta memperhatikan budaya yang dianut oleh masyarakat pengembangan pariwisata tersebut dilakukan. Pemeliharaan fasilitas wisata sering menjadi faktor yang terabaikan pada destinasi wisata yang sedang berkembang. Pengelola lebih fokus pada upaya pengembangan dan mendatangkan pengunjung. Hal ini karena pemeliharaan fasilitas wisata cenderung mendatangkan biaya dari pada keuntungan. (Yulianto, 2020).

Salah satu jenis pariwisata adalah marine tourism yang merupakan kegiatan wisata yang ditunjang oleh sarana dan prasarana laut dengan berbagai kegiatannya, seperti berenang, memancing, menyelam, dan olah raga lainnya, termasuk sarana dan prasarana akomodasi, makan dan minum. Sea tourism yaitu kegiatan kepariwisataan yang menggunakan angkutan laut untuk mengunjungi suatu daerah tujuan wisata. Pariwisata laut yang diselenggarakan oleh Pemerintah Provinsi Banten, selain yang sudah sangat terkenal adalah wisata laut Anyer, ada pula Wisata laut Pulau Panjang dan Pulau Tunda. Pulau Tunda merupakan salah satu gugusan pulau dari 17 pulau yang berada di Kabupaten Serang Provinsi Banten. Secara administratif, Pulau Tunda terletak di Kecamatan Tirtayasa, Kabupaten Serang, Provinsi Banten. Dilihat secara geografis Pulau tunda terletak di koordinat $5^{\circ} 48^{\prime} 43^{\prime \prime}$ LS dan $106^{\circ} 16^{\prime} 47^{\prime \prime}$ BT .Letaknya yang berada di sebelah utara Teluk Banten memiliki luas sekitar 300 hektar are, sebanyak $400 \mathrm{kk}$ dan memiliki jumlah penduduk sekitar penduduk di atas orang. Di Pulau Tunda terdapat 1 desa yaitu Desa Wargasara dan terdiri atas 2 dusun yakni Kampung Barat dan Kampung Timur. Pekerjaan penduduk desa umumnya adalah buruh nelayan, bercocok tanam palawija, dan sebagian kecil sebagai pedagang perantara.(ulistian, 2016).

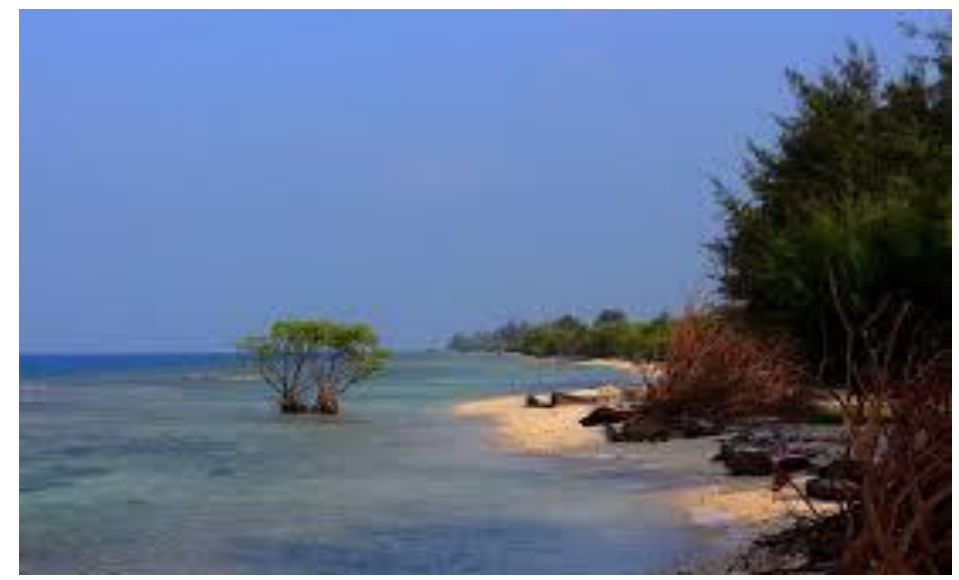

Gambar 1. Salah Satu Pantai di Pulau Tunda 
Pengembangan pariwisata di suatu objek daerah tujuan wisata harus didasarkan pada perencanaan, pengem-bangan, dan arah pengelolaan yang jelas agar semua potensi yang dimiliki suatu daerah tujuan wisata dapat diberdayakan secara optimal untuk meningkatkan kesejahteraan masyarakat. Langkah pertama dimulai dari inisialisai dan komitmen kuat dari pemerintah untuk mengarahkan program-program pengembangan pariwisata ke pelibatan masyarakat lokal, baik sebagai penyedia jasa maupun sebagai pengguna jasa itu sendiri. Tanpa adanya keikutsertaan dan partisipasi masyarakat, pembangunan pariwisata hanya akan melahirkan produk-produk wisata yang kurang berarti bagi masyarakat dan tidak sesuai dengan kebutuhan masyarakat. Pengembangan pariwisata yang seperti ini dianggap lebih tepat dan proporsional bagi kesejahteraan khususnya ma-syarakat lokal. Dari studi-studi atas berbagai proyek pengembangan pari-wisata tersebut terlihat suatu pola yang relatif sama tentang bagaimana seharusnya pengembangan pariwisata dilakukan dan dikelola agar dapat meningkatkan kesejahteraan masyarakat khususnya di sekitar kawasan wisata.(Sayogi \& Dermatoto, 2009).

Terdapat banyak kegiatan yang bisa dilakukan di pantai maupun lautan. Berikut ini adalah beberapa kegiatan yang bisa dilakukan di laut dan pantai, yaitu : menjelajahi dan menikmati keindahan alam bawah laut yang sangat menakjubkan. Terdapat banyak sekali biota laut dan juga batu karang yang sangat indah di dasar lautan. Dengan menjelajahi dasar lautan, kita bisa menikmati keindahan tersebut sekaligus mempelajari banyak hal baru. Kegiatan menjelajahi alam bawah laut sering disebut dengan Sea Walker yang berarti menjelajahi lautan. Kegiatan menjelajahi ini biasanya sering dilakukan disekitar pantai atau perairan dangkal, diving dan juga snorkeling. Kegiatan ini dilakukan dengan menggunakan peralatan menyelam. Tujuan kegiatan ini selain untuk rekreasi juga sebagai sarana untuk mempelajari keragaman kehidupan yang ada di lautan; Olahraga Air. Jenis kegiatan seperti Speedboat, berselancar dan Mengayuh perahu masuk dalam kategori ini.

Selain itu, Wisata Bahari memiliki banyak sekali potensi. Jenis wisata kelautan akan memiliki dampak secara langsung pada warga masyarakat di sekitar pantai dan lautan. Warga sekitar bisa mendapatkan penghasilan tambahan dari menawarkan jasa maupun produk kepada wisatawan. Adapun sektor ekonomi juga akan bergerak ke arah positif seiring dengan semakin cepatnya perputaran uang dan jasa di suatu wilayah.Meningkatkan pendapatan daerah. Pendapatan daerah dari sektor wisata akan naik secara signifikan; Sarana Konservasi, setiap wisatawan bisa mengetahui beragam hal yang berkaitan dengan dunia kelautan dan diharapkan hal tersebut bisa menambah kesadaran untuk menjaga kelestarian alam; Sarana Pendidikan.Tiada hal yang lebih baik dari belajar secara langsung dengan melihat dan mengetahui objek yang sedang dipelajari. Dengan melakukan kegiatan rekreasi bahari setiap 
wisatawan akan mendapatkan pengetahuan mengenai banyak hal yang berkaitan dengan kelautan.

Keunikan jenis wisata ini yang membedakannya dengan Pariwisata yang lain:

1. Terdapat banyak hal baru yang bisa dipelajari. Saat berjalan di sekitar pantai, akan menjumpai banyak hal baru yang bahkan mungkin tidak pernah dijumpai sebelumnya. Begitu juga saat menjelajahi lautan. Akan terdapat begitu banyak hal yang bisa diketahui dari kegiatan tersebut.

2. Lokasi cukup sejuk dan lapang. Jenis Pariwisata Kelautan pada umumnya memiliki lokasi yang sangat luas serta terdapat hembusan angin yang cukup sejuk untuk dirasakan.

3. Menikmati keindahan matahari yang muncul dan tenggelam di lautan. Menikmati pesona matahari yang muncul saat fajar menyingsing serta saat tenggelam di waktu senja terasa sangat luar biasa.

4. Pengunjung bisa menikmati ikan hasil tangkapannya dari laut. Pada jenis wisata lain, hal ini tentu saja tidak bisa dilakukan.

Pulau Tunda sudah dijadikan objek pariwisata yang sangat menarik karena memiliki keindahan pantai dan laut yang bisa dieksplore sebagai daya tarik bagi wisatawan. Kegiatan berlayar dengan pemandangan laut dan lumba-lumba, memancing, snorkeling, diving, melihat sunset dan sunrise adalah potensi wisata yang menarik. Kekuatan Pulau Tunda terutama ada pada kondisi taman bawah laut yang masih terjaga, lahan perekebunan dengan kondisi tanah yang cukup baik, dan ketersediaan air tawar dari Pulau Tunda itu sendiri. Sebagai destinasi wisata bahari, wisata Pulau Tunda diharapkan menerpakan wisata bahari berkelanjutan, yang terus menjaga kelestarian lingkungan hidup, dengan pelibatan masyarakat setempat serta memperhatikan budaya yang dianut oleh masyarakat di Pulau Tunda.

Untuk mencapai Pulau Tunda, wisatawan bisa melakukan perjalanan melalui Pelabuhan Karangantu dengan menggunakan perahu motor kayu milik nelayan setempat dengan lama perjalanan mengarungi lautan sekitar 2 jam. Selain menyewa kapal untuk ke Pulau Tunda, wisatawan juga bisa menggunakan KMP Tunda yang melayani transportasi untuk masyarakat setempat. Jadwal kapal dari Pelabuhan Karangantu ke Pulau Tunda, berangkat sekitar pukul 13.00 WIB, sedangkan jadwal kapal dari Pulau Tunda ke Pelabuhan Karangantu, berangkat pukul 07.00 WIB. Karena belum banyak dikunjungi wisatawan seperti destinasi mainstream lain, biota laut di perairan Pulau Tunda masih terjaga. Bahkan jika beruntung Anda memang dapat melihat lumba-lumba berenang, khususnya saat air laut. 


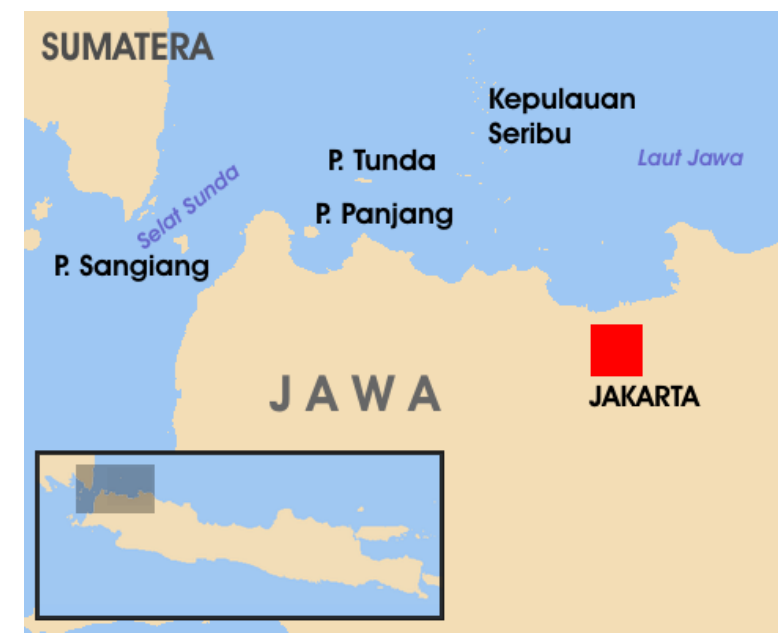

Gambar 2. Lokasi Pulau Tunda

Kegiatan pariwisata di Pulau Tunda dibina oleh Dinas Pemuda Olahraga dan Pariwisata (Disporapar) Kabupaten Serang. Masyarakat Pulau Tunda dilatih untuk siap membantu para wisatawan melakukan kegiatan di Pulau tersebut. Selain dibentuk kelompok sadar wisata (Pokdarwis), masyarakat juga mempersiapkan rumah-rumah tinggal mereka sebagi tempat menginap (homestay) bagi wisatawan. Selama menginap disini, wisatawan mendapat fasilitas makan yang disediakan oleh pemilik rumah.

Homestay, secara prinsip, merupakan rumah tinggal penduduk di desa wisata yang sebagian kamarnya disewakan kepada wisatawan serta adanya interaksi antara wisatawan dengan pemilik rumah (Kemenpar 2016). Adapun fungsi homestay antara lain; 1) homestay sebagai sarana akomodasi di desa wisata, 2) homestay sebagai bagian atraksi (daya tarik) dari desa wisata, 3) sebagai sarana interaksi antara wisatawan dengan tuan rumah, 4) sebagai sarana edukasi bagi wisatawan untuk belajar kearifan lokal, 5) sebagai sarana pengenalan budaya. Dalam pengertiannya, homestay merupakan konsep akomodasi yang seharusnya sesuai jangkauan secara ekonomi dengan kelebihan mengalami kehidupan lokal yang orisinil karena menyatu dengan kehidupat keseharian masyarakat desa. Dengan konsep tersebut maka pengembangan dapat dilakukan dengan memastikan kesadaran muncul dalam komunitas masyarakat desa sehingga pertumbuhan organik tersebut digerakkan secara natural dan sadar. Berdasarkan hal tersebut maka dapat dikatakan pada homestay, selain dijadikan sebagai saran menginap wisatawan, namun dapat juga dijadikan sebagai atraksi wisata yang dengan membuat produk wisata yang berbasiskan kepada homestay (Dea Prasetyawati, 2018). Home stay bisa juga disebut sebagai pondok wisata yang merupakan usaha jasa pelayanan penginapan bagi umum yang dilakukan perorangan dengan menggunakan sebagian atau seluruh dari tempat tinggalnya (dengan pembayaran harian). 


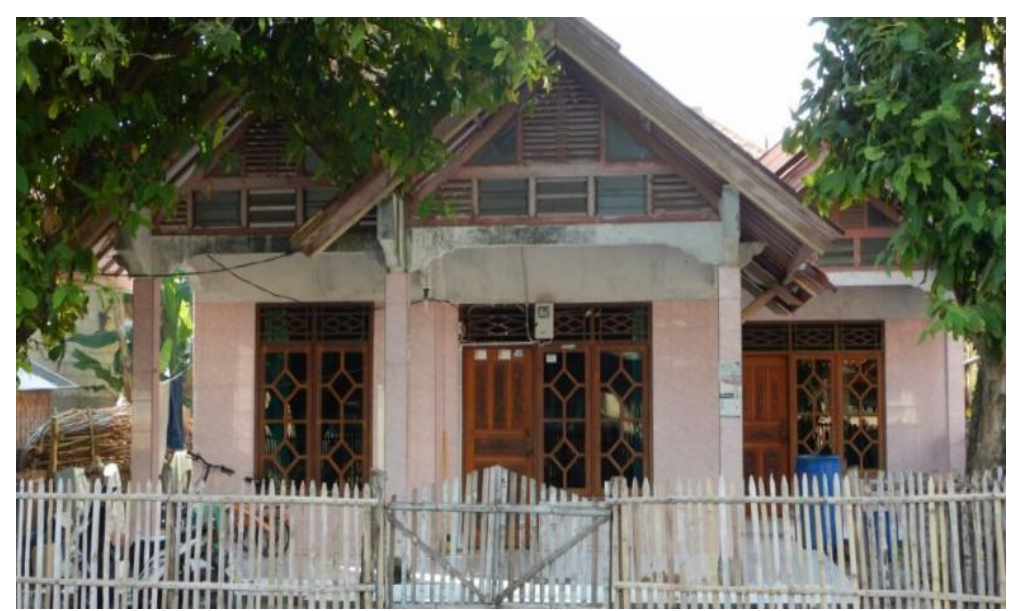

Gambar 3. Salah Satu Homestay di Pulau Tunda

Lembaga Penelitian dan Pengabdian Mayarakat (LP3M) Universitas Banten Jaya mendapatkan kepercayaan dari Dinas Pemuda Olahraga dan Pariwisata (Disporapar) Kabupaten Serang sebagai Lembaga pendamping Desa Wisata Pulau Tunda untuk meningkatan kualitas sumber daya manusia dalam bidang pariwisata. Tim Pengabdian Kepada Masyarakat (PKM) dari Universitas Banten Jaya (UNBAJA) bersama dengan perwakilan Disporapar Kabupaten Serang yang juga sedang melakukan monitoring kegiatan pelatihan bagi Kelompok Sadar Wisata (Pokdarwis), mengadakan kegiatan demo masak yang diperagakan oleh juru masak (Chef) dengan menggunakan bahan masakan lokal (ikan laut, buah sukun, pisang kepok) yang ada di Pulau Tunda agar masyarakat mempunyai tambahan alternatif menu makanan yang bisa disajikan kepada wisatawan. Selain itu juga agar bahan masakan lokal bisa mendapatkan nilai rasa dan estetika lebih tinggi dari cara mengolah sampai cara penyajian, yang secara tidak langsung dapat meningkatkan perekonomian nelayan dan keluarga-keluarga di Pulau Tunda.

Sejauh ini, kraetivitas masyarakat Pulau Tunda dalam menciptakan varias menu makanan yang disajikan kepada wisatawan masih sangat minim. Masih rendahnya motivasi, minat serta mental berwirausaha di kalangan penduduk serta belum memahami tentang pentingnya kearifan lokal khususnya pada kuliner lokal, yang menjadi bagian pembangunan wisata Pulau Tunda. Padahal, tingginya perkembangan industri pariwisata dapat memberikan peluang yang sangat besar bagi masyarakatnya, untuk ikut berpartisipasi dalam pembangunan wisata kuliner, yang saat ini masih sangat terbatas, jumlahnya. Kondisi Pulau Tunda sebagai pulau tujuan wisata dapat di tampilkan dalam bentuk table kekuatan (strength), kelemahan (weakness), peluang (opportunity) dan ancaman (threat) SWOT seperti di bawah ini: 
Tabel 1. SWOT Pulau Tunda

\begin{tabular}{lllll}
\hline No & Strength & Weakness & Opportunity & Threat \\
$\mathbf{1}$ & $\begin{array}{l}\text { Daya Tarik alam dan } \\
\text { keindahan pantai }\end{array}$ & $\begin{array}{l}\text { Kurangnya } \\
\text { informasi dan } \\
\text { promosi wisata }\end{array}$ & $\begin{array}{l}\text { Menumbuhkan } \\
\text { kesejahteraan } \\
\text { masyarakat lokal }\end{array}$ & $\begin{array}{l}\text { Terjadinya } \\
\text { perubahan } \\
\text { lingkungan }\end{array}$ \\
\hline $\mathbf{2}$ & Potensi riset dan konservasi & $\begin{array}{l}\text { Lemahnya } \\
\text { sumberdaya } \\
\text { manusia dan } \\
\text { hukum }\end{array}$ & $\begin{array}{l}\text { Peningkatan } \\
\text { wisatawan local } \\
\text { dan mancanegara }\end{array}$ & $\begin{array}{l}\text { Kurangnya } \\
\text { keamanan } \\
\text { berwisata }\end{array}$ \\
& & $\begin{array}{l}\text { Kurangnya } \\
\text { koordinasi antara } \\
\text { pengelola, } \\
\text { masyarakat dan } \\
\text { berbagai pihak. }\end{array}$ & \\
\hline $\mathbf{3}$ & Keaslian dan kealamian \\
& pantai di P. Tunda & $\begin{array}{l}\text { Lemahnya sarana } \\
\text { dan prasarana }\end{array}$ & \\
& & $\begin{array}{l}\text { Lemahnya } \\
\text { kreativitas } \\
\text { mahasiswa } \\
\text { masyarakat lokal }\end{array}$ & \\
\hline $\mathbf{4}$ & Atraksi wisata mayarakat \\
setempat & & & \\
\hline $\mathbf{5}$ & & & \\
& & & \\
& & & \\
\end{tabular}

Kuliner merupakan salah satu jenis wisata yang mengedepankan makanan lokal, yang memiliki peran penting dan akan menjadi pengalaman baru bagi wisatawan. Pengalaman baru dapat diperoleh wisatawan berupa keunikan cita rasa, penggunaan bumbu tradisional, cara pengolahan serta kemasan yang bersifat tradisional. Penyediaan fasilitas makanan dan minuman tentu saja tidak dapat dipisahkan dari kebutuhan wisatawan sebagai bagian dari produk wisata. Dengan alasan bahwa keinginan untuk memberi kepuasan bagi wisatawan, membuat para pengusaha yang bergerak dalam penyediaan makanan dan minuman melakukan berbagai usaha untuk menyediakan berbagai hidangan yang sesuai dengan "taste" wisatawan yang datang dari berbagai negara. (Syarifuddin et al., 2018). Daya tarik wisata di Pulau Tunda selain keindahan pantai dan taman bawah lautnya adalah semua produk yang berupa makanan dan jajanan tradisional dan menarik bagi wisatawan untuk menikmatinya. Upaya menciptakan daya tarik wisata, adalah bagian dari adaptasi menu dalam pengembangan produk atau kreasi menu restoran yang sebaiknya dimulai atau diakhiri berdasarkan pada keinginan konsumen, intinya bagaimana supaya dapat menjangkau keinginan konsumen.

\section{METODE}

Metode yang dilakukan dalam kegiatan pengabdian kepada masyarakat ini adalah metode deskriptif kualitatif dengan kegiatan pertemuan tatap muka, dengan mengundang masyarakat 
Pulau Tunda dan perwakilan Kelompok Sadar Wisata untuk mengikuti demo masak yang diadakan pada hari Juma't, 18 September 2020 pukul 14.00 s/d selesai. Dengan bertempat di salah satu halaman rumah penduduk Pulau Tunda.

\section{HASIL DAN PEMBAHASAN}

Kekuatan yang menjadi daya Tarik wisatwan di Pulau Tunda adalah keindahan pantai dan taman bawah lautnya, selain adanya homestay dan keramahan penduduknya dalam melayani wisatawan yang datang. Diharapkan dengan dikembangkannya destinasi ini dapat meningkatkan kesejahteraan pengelola dan warga sekitarnya dari lahan yang kurang produktif menjadi destinasi yang menarik wisatawan untuk berkunjung menikmati keindahan alam yang ditawarkan. Hasil dari kegiatan demo memasak adalah berupa menu amakanan yang memiliki rasa dan tampilan yang berbeda dibandingkan dengan dengan hasil masakan yang biasa disajikan kepada tamu wisatawan di Pulau Tunda. Masyarakat dapat membuat menu yang baru dari bahan masakan lokal dan terlihat antusias mengikuti kegiatan demo memasak, serta mau mencoba menyajikannya kepada tamu yang datang ke Pulau Tunda. Berikut ini adalah perbedaan hasil masakan sebelum dan sesudah dilakukan demo memasak.

Tabel 2. Perbedaan Menu Sebelum dan Sesudah Kegiatan Demo Masak

\begin{tabular}{|c|c|c|c|}
\hline $\begin{array}{c}\text { Bahan } \\
\text { Masakan }\end{array}$ & Sebelum Demo Masak & Sesudah Demo Masak & Perbedaan \\
\hline Ikan & Dibakar, digulai, digoreng & $\begin{array}{l}\text { Dihaluskan isinya, diberi bumbu, } \\
\text { dimasukkan kembali ke tubuh } \\
\text { ikan, dibakar, dan disajikan } \\
\text { dengan hiasan (Garnis). }\end{array}$ & $\begin{array}{lr}\text { Cara } & \text { mengolah, } \\
\text { rasa, } & \text { dan } \\
\text { tampilan lebih } \\
\text { baik }\end{array}$ \\
\hline Buah Sukun & Digoreng biasa, dikukus & $\begin{array}{l}\text { Dikukus, disajikan dengan kelapa } \\
\text { parut, sajian dihias dengan daun } \\
\text { pandan }\end{array}$ & $\begin{array}{lr}\text { Cara } & \text { mengolah, } \\
\text { rasa, } & \text { dan } \\
\text { tampilan lebih } \\
\text { baik }\end{array}$ \\
\hline $\begin{array}{l}\text { Pisang } \\
\text { kepok }\end{array}$ & Digoreng, dikukus & $\begin{array}{l}\text { Dibakar, disajikan dengan kuah } \\
\text { gula merah, dan sajian dihias } \\
\text { dengan daun pandan }\end{array}$ & $\begin{array}{lr}\text { Cara } & \text { mengolah, } \\
\text { rasa, ran } \\
\text { tampilan lebih } \\
\text { baik }\end{array}$ \\
\hline
\end{tabular}




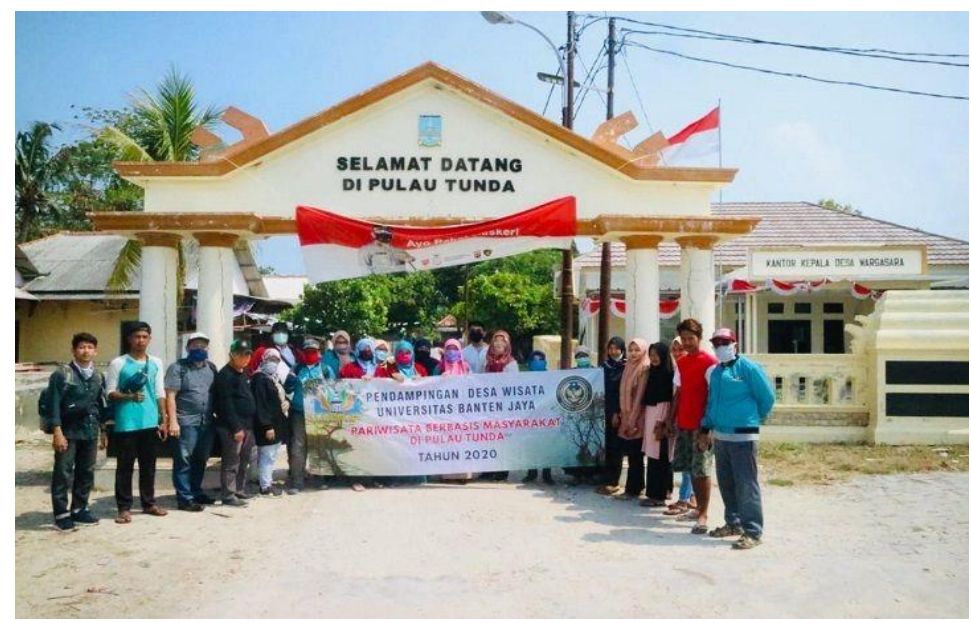

Gambar 4. Tim Pengabdian Kepada Masayarakat (PKM) UNBAJA

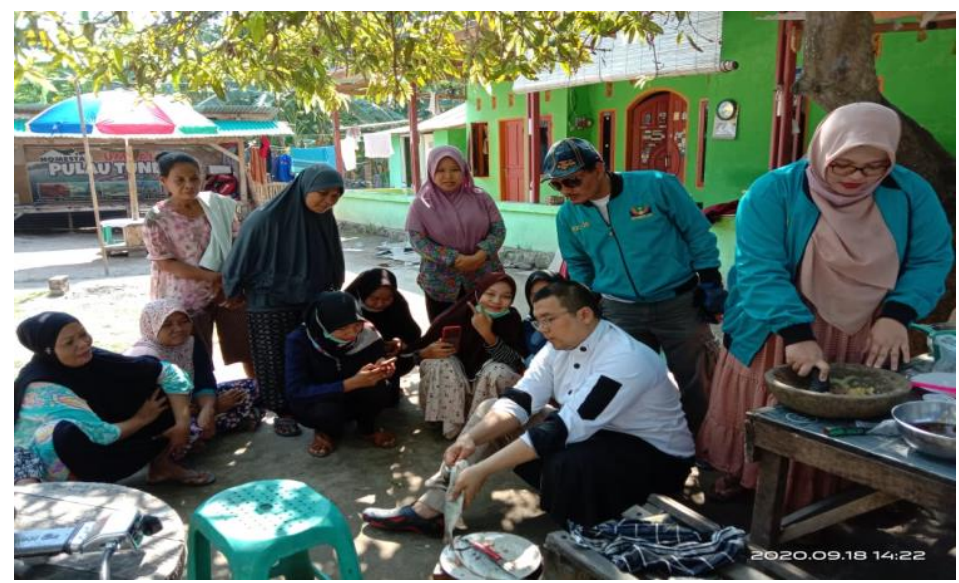

Gambar 5. Kegiatan Demo Masak PKM UNBAJA 2020

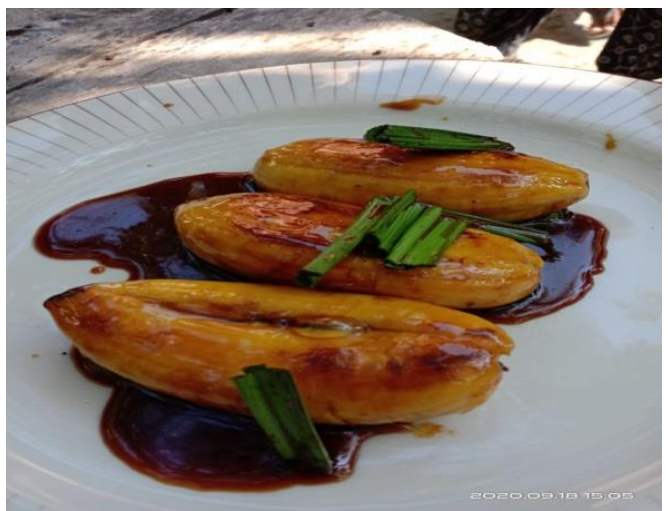

Gambar 6. Contoh Menu Baru Berbahan Pisang Kepok Hasil Pulau Tunda 
Adapun dalam kegiatan ini, cara membuta menu pisang gula merah, adalah: Membuat saus gula merah terlebih dahulu, dengan cara merebus air, gula jawa, gula pasir dan garam sampai mendidih dan sedikit mengental, kemudian sisihkan. Selanjutnya adalah mengupas pisang, dan penyet dengan panggang di atas teflon sampai matang kedua sisinya. dengan api sedang. Terakhir adalah menata pisang diatas piring, siram saus gula. bisa diberi toppingan parutan keju/parutan coklat milo atau diberi siraman skm.

\section{KESIMPULAN}

Wisata bahari merupakan sebuah tempat rekreasi yang memberi dampak positif bagi lingkungan dan juga perekonomian. Jenis rekreasi ini cukup banyak terdapat di seluruh Indonesia karena tipe negara kita adalah negara kepulauan yang disatukan oleh lautan. Dari hasil kegiatan pengabdian ini, masyarakat Pulau Tunda memiliki tambahan pengetahuan tentang mengolah bahan makanan lokal seperti ikan, buah sukun dan pisang kepok serta dapat menyajikannya dengan rasa dan tampilan yang lebih baik, sehingga memiliki nilai estetika yang lebih tinggi yang dapat menimbulkan selera makan dan minat wisatawan yang datang ke Pulau Tunda. Selain itu, dapat menimbulkan kesan yang baik yang dapat menjadi informasi bagi masyarakat agar tetarik mengunjungi. Pulau Tunda. Jika jumlah wisatawan yang datang ke Pulau Tunda meningkat, diharapakan akan meningkatkan kegiatan perekonomian masyarakat dan pada akhirnya dapat meningkatkan pendapatan masyarakat setempat.

\section{UCAPAN TERIMA KASIH}

Atas terlaksananya kegiatan ini, saya mengucapkan terimakasih kepada

1. Pimpinan Universitas Banten Jaya.

2. Lembaga Penelitian dan Pengabdian Masyarakat Universitas Banten Jaya.

3. Tim Pengabdian Kepada Masyarakat (PKM) Universitas Banten Jaya 2020.

4. Perwakilan Dinas Pemuda Olahraga dan Pariwisata (Disporapar) Kabupaten Serang, Pembina Kelompok Sadar Wisata Pulau Tunda.

5. Kelompok Sadar Wisata Pulau Tunda.

6. Chef Mulya

7. Masyarakat Pulau Tunda

\section{DAFTAR PUSTAKA}

Prasetyawati, D. (2018). Capacity Building for Homestay Management in Batulayang Tourism Village, Bogor Regency. Proceeding of Community Development. Volume 2 (2018): 627633; DOI: https://doi.org/10.30874/comdev.2018.311. 
Nugroho. (2020). Beberapa Masalah dalam Pengembangan Sektor Pariwisata di Indonesia. Pariwisata, Vol. 7 No. 2, September 2020.

Sayogi \& Dermatoto. (2009). Studi Deskiptif Pada Pelaku Pengembangan Pariwisata Bahari Pantai Watukarung Desa Watukarung Kecamatan Pringkuku Kabupaten Pacitan. Journal of Development and Social Change, Vol. 1, No. 1, April 2018: P. 9-17 p-ISSN 26145766, https: //jurnal.uns.ac.id/jodasc.).

Yulianto. (2020). Strategi Pemeliharaan Dan Pengembangan Fasilitas Wisata Bagi Kenyamanan Pengunjung Pule Payung Yogyakarta. Pariwisata, Vol. 7 No. 2, September 2020

Sulistian. (2016). Pulau Tunda sebagai daerah Tujuan Wisata Bahari Kabupaten Serang. Skripsi. Universitas Sultan Ageng Tirtayasa. Tidak diterbitkan.

Syarifuddin et al. (2018). Memaknai Kuliner LokalSebagai Daya Tarik Wisata Kota Bandung. Jurnal Abdimas Bsi. Jurnal Pengabdian Kepada Masyaraka. Vol. 1 No. 1 Februari 2018, Hal. 55-64. https://doi.org/10.31294/jabdimas.v1i1.2866.g1859. 